\title{
Tree Diversity and Management of Village Common Forests in Bandarban
}

\author{
Kamrul I. Kamrul ${ }^{1,}$, Jashimuddin Jashimuddin ${ }^{2}$, Nuralam Hossain ${ }^{3}$ \\ ${ }^{1}$ Community Development Centre (CODEC), C/O Serajul Islam, S E Complex, College Gate, \\ Rangamati Sadar, 4500 Rangamati, Bangladesh \\ ${ }^{2}$ Institute of Forestry and Environmental Sciences, University of Chittagong, Chittagong 4331, \\ Bangladesh \\ ${ }^{3}$ Chongqing University, Chongqing, 400045, China
}

Received: 29 July 2017

Accepted: 11 September 2017

Published online: 30 December 2017

\begin{abstract}
Village Common Forests (VCF) are used sustainably for water source conservation, livelihoods and other biomass needs ofethnic communities in the hilly areas of Bangladesh. The current forest degradation rate warrants the importance and potentiality of VCF for sustainable natural resources management. This study was conducted in two VCF of Lama and RumaUpazila at Chimbuk hill range in Bandarban district to explore the indigenous management techniques and tree species diversity. To identify tree species diversity, eighteen plots ( 9 plots from each VCF) were selected at different hill position (top, middle and bottom) by stratified random sampling method with the dimension of $20 \mathrm{~m} \times 20 \mathrm{~m}$ per plot. Shiner-winner and Simpson index were used to calculate the tree species diversity. According to the analyses, it was found that diversity was higher in top of the hill, but species density (stem/ha) was higher in the valley. It was also found that 23000 seedlings/ha regenerated naturally and among the 31 identified families, Moraceae was dominant where the density was $354 \mathrm{stems} / \mathrm{ha}$ with basal area $52.63 \mathrm{~m} 2 / \mathrm{ha}$. The dominant species were Schleicher oleosaand Anisopterascaphula and important non-timber species were Melocannabaccifera and Calamusgurubagrowing abundantly in the study areas. It was observed that the VCF were managed by ethnic Mro community with two different committees (customary and executive) who made some rules for natural forest conservation. This management practice is not only conserving hill forests, but also helping to improve degraded forest and create new habitats for biodiversity in the study area.
\end{abstract}

Keywords: species, sustainable, Indigenous

\section{Introduction}

Chittagong Hill Tracts (CHT) with an area of $13,191 \mathrm{~km}^{2}$ and located at $21.25^{\circ}$ and $23.45^{\circ} \mathrm{N}$ latitudes, and $91.45^{\circ}$ and $92.50^{\circ} \mathrm{E}$ longitudes, which is one of the forest rich areas in Bangladesh. The

${ }^{*}$ Corresponding author: K. I. Kamrul
e-mail: kamrul.forestry@ gmail.com 
region is characterized by the undulating hills and valleys, and its unique flora and fauna. The elevation of the hills in this watershed is less than 300m (Gupta, 2008). It consists of several valleys consecutively in a northwest to south easterly direction with ridges rising to $900 \mathrm{~m}$ (Amnesty International, 2008). The inhabitants of this area are also different from other parts of the country (Nishat and Biswas, 2010). Bandarban district is a part of the CHT in the southeastern part of the country and has a total area of 4,502 sq. km including 751 sq. km of reserve forest and 2,125 sq. km of unclassed state forest (Nath et al., 1998). Like other 13 different ethnic groups (Ishaq, 1971), Mro community is basically forest dependent and their culture, livelihoods and lifestyle are almost related to forest and it resources. Traditionally, the ethnic communities practice a farming method called jhumcultivation, which basically involved in cultivation of food crops in forest land by clearing and burning of undergrowth in the dry season. However, this practice was not so much effective to meet the livelihood demands sustainably in the same forest land for ethnic people and gradually reduce natural forest and dryness the natural water stream from the hill. Water supply is very important for every production activities in the hill areas. To make sustainabletheir livelihoods and conserve natural forest \&its natural water source, ethnic people have introduced a forest management system through which a large tract of hilly natural forest area, which commonly known as Village Common Forest (VCF), is conserve collectively. Ethnic community in the surrounding VCF sets some rules to conserve this natural forest. VCF meet the demand of bamboo, timber, medicinal plants, fuel wood and other minor forest product of ethniccommunity (Chakma, 2005). A study conducted by Hossain et al. (2013), overexploitation of forest resources has caused severe damage to the forest ecosystem which led to rapid loss of biodiversity.The current alarming rate of forest degradation in the Bandarban district is warrants an evaluation of the strategic importance and potential of the VCF for sustainable natural resources management and biodiversity conservation in the hilly area. Hence, the protection and preservation of VCF become crucial for livelihood, environmental, medicinal, cultural and religious needs of indigenous communities (Misbahuzzaman and Marma, 2008) However, the management of VCF sets an example of sustainable forest management. Therefore, this study was carried out to identify the tree species diversity in the VCF and to explore the existing indigenous management system of VCF.

\section{Materials and Method}

\subsection{Location of the Study area}

The study was carried out in two sub-districts named Lama and Ruma of Bandarban district in Bangladesh (Fig. 1). RumaUpazila is lies between $21^{\circ} 53^{\prime} \mathrm{N}$ to $22^{\circ} 10^{\prime} \mathrm{N}$ and $92^{\circ} 17^{\prime} \mathrm{E}$ to $92^{\circ} 34^{\prime} \mathrm{E}$ with an area of $492.10 \mathrm{~km}^{2}$ and Lama Upazila is located at $21^{\circ} 36^{\prime} \mathrm{N}$ to $21^{\circ} 59^{\prime} \mathrm{N}$ and $92^{\circ} 04^{\prime} \mathrm{E}$ to $92^{\circ} 23^{\prime} \mathrm{E}$ with an area of $671.84 \mathrm{~km}^{2}$ which are covered by high hilly area(Banglapedia, 2014). The study sites is located at Korangpara, 5 No. ward of 4 No. Kalenga Union, RumaUpazilaand Kaprupara, 9 No. ward of 5 No. Sorai Union, Lama Upazila. Both sites aresituated at Bandarban-Thanchi road about $39 \mathrm{~km}$ and $45 \mathrm{~km}$ away from Bandarban Sadar. Both village and its VCFs are the very beautiful villages which is inhabited by 183 people in Korangparaand 270 in Kaprupara. All the population of the study area is from Mro ethnic community and belongs to Christianity and Crama by religion. The main livelihoods were traditional agriculture where no modern technology was used and soil formation was flood plain, grey piedmont, hill brown and terrace. The Hills are underlain by sandstone, siltstone and shale of Tertiary and Quaternary ages. Landscape is steep and soils were mainly developed on steep slopes and some occur on more gentle slopes. Paddy, sesame, cotton, turmeric, ginger and vegetables are common agricultural crops in the study area and while banana, jackfruit, papaya, orange, malta are the most common cultivated horticulture crops. Previous studies on this aspect were carried out in other subdistricts of Bandarban in Bangladesh where land value and demographic pressure on forests are 
comparatively less than our study areas. Therefore, studying the tree species composition and diversity seems relevant to find the current management system of village common forest. Additionally, this study will give a chance to compare the results with previous studies.

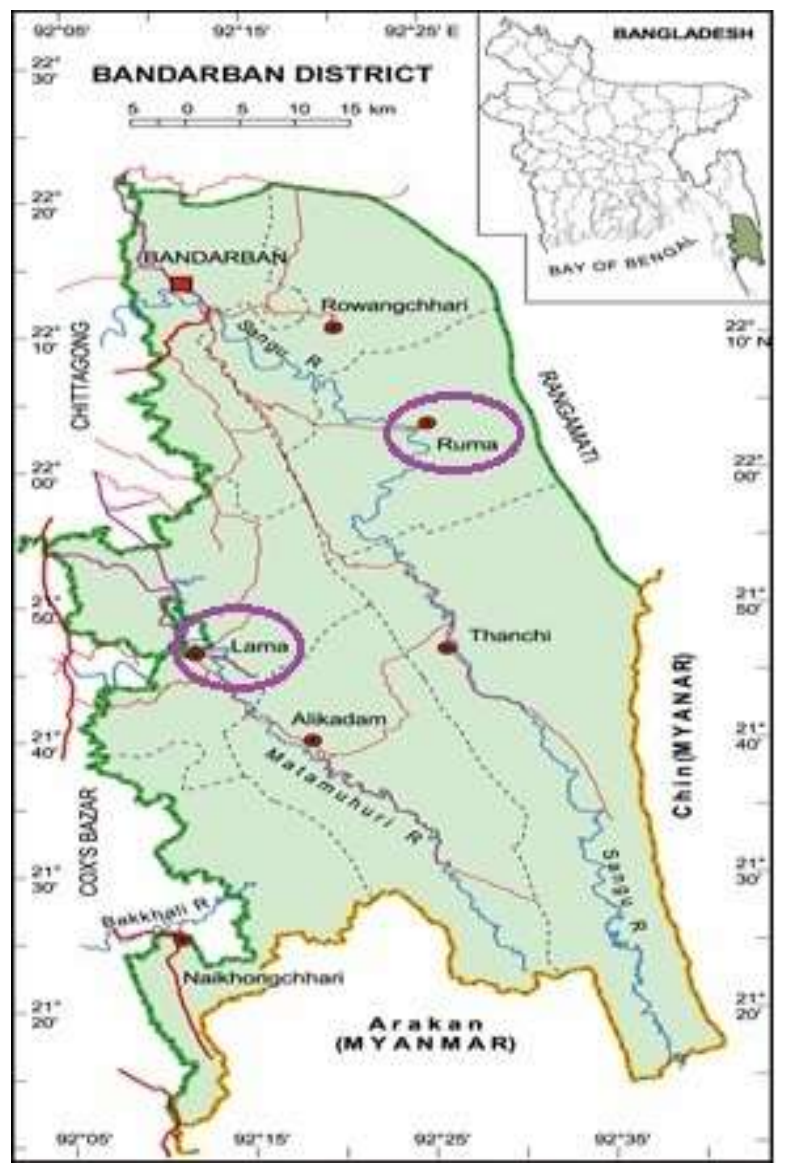

Fig. 1 Map of Lama and Ruma sub-districts of Bandarban in Bangladesh (Purple color circled); Source: Banglapedia.

\subsection{Sampling design and data collection}

To obtain an idea on general physiography, socio-economic condition, household characteristics, reconnaissance survey and trail hiking was carried out in the study area. Based on availability of VCF and working facility, two villages named Korangpara from RumaUpazila and Kaprupara from Lama Upazilawere selected purposively. The study was conducted during April 2016 to March 2017 and visited all the households (a total of 63 households both in Korangpara and Kaprupara) of the villages for identifying and gathering information on floral diversity of VCF.

The study was carried out following two different methods namely face-to-face interview and vegetation survey. We used semi-structured questionnaire, 5 key informant interviews (KII) and 6 Focus Group Discussion (FGD) for data collection. The socio-economic information was collected from the households and validated by key local informants, such as school teachers, village heads, and religious and political leaders. Forest survey was conducted to know the species diversity and regeneration status of the study area. In case of forest survey of each VCF, stratified random sampling was used for getting a complete picture of the whole area with 9 sample plots in each VCF. The sampling plot size for tree species was $20 \mathrm{~m} \mathrm{X} \mathrm{20m.} \mathrm{From} \mathrm{each} \mathrm{plot,} \mathrm{height} \mathrm{and} \mathrm{dbh} \mathrm{of} \mathrm{all} \mathrm{tree} \mathrm{species} \mathrm{were}$ measured by using Spiegel Relascope and diameter tape. To know regeneration status of tree species, 4 subplots of $2 \mathrm{~m} \times 2 \mathrm{~m}$ were taken at the corner point of each main plot. Number of seedlings of each 
K. I. Kamrul et al.

species were enumerated and identified from the sub-plots. Photos of twigs and trees were taken for the identification of the unknown species with the help of local people, experts from Bangladesh Forest Research Institute (BFRI) and available literatures.

\subsection{Functional diversity}

According to Martinez (1966), functional diversity of any forest area is defined as the variety of interactions with ecological processes and can be quantified by examine the nature of forest and extent to which functional groups are represented in an ecological system. Functional diversity can also refer to the number of such groups or species in a forest community, each of which contains one or more species (Smith and Huston, 1989). Functional diversity, evenness and richness were measured using different world recognized method.

\subsection{Shannon - Weaver index}

Diversity index was computed by using the Shannon-Weaver (Eq. 1) information index Shannon - Weaver index, 1963), which is as:

$$
H^{\prime}=-\sum_{j=1}^{N s p p} P i \ln P i
$$

Where, quantity $P i$ is the proportion of individuals found in the $i$ thspecies, and is estimated using the maximum likelihood estimator (Eq. 1):

$$
P_{i}=\frac{n_{i}}{N}
$$

Where $n_{i}$ is the number of individuals in the $i$ th species. $N$ is the total number of individuals of all species and $P i$ is the evenness of each species. The Shannon-Weaver index indicates species diversity of an area or forest. The higher the value, the higher will be the diversity. If the diversity is the more, this indicates less competition between species. If the value is lesser, this indicates that competition has narrowed down the amount of species able to make a living in that an area or forest.

\subsection{Simpson's Index}

One of the best-known diversity index based on measures of the quantities of different species in each sample plot is Simpson's index of Concentration. Concentration of dominance (D) was measured by using in the calculation of the Simpson's Index (Eq. $1,2)$, which is usually formulated as (Simpson, 1949):

$$
D=\sum P_{i}^{2}
$$

Where,

$$
P_{i}=\frac{n_{i}}{N}
$$

The Simpson's Index produces higher values for lowerdiversity and is often expressed as 1-D. 
K. I. Kamrul et al.

\subsection{Data analysis}

The tree species found in two studied VCF have been recorded and identified by their respective local Bangla name, English name, scientific name, type, number and their relative abundance. Here, we found that some species are more frequent than others based on the slope of the hill and availability of sunlight. Therefore, to calculate the percentage distribution of all species we separated the major species in order to avoid minimum contributory species. Data of management techniques of VCF were taken by FGD and maximum percentage have taken into consideration. Data analysis was carried out by Microsoft Office Excel-2016.

\section{Result}

\subsection{Tree Species Diversity}

There were 41 tree species belonging to 28 families found in the study area. The dominant family was Moraceae with 5 species followed by Anacardiaceae with 4 species, Apocynaceae, Bigononiaceae, Combrataceae, Dipterocarpaceae and Mimosaceae with 2 species and the remaining families possessing only one species. Mulibansh (Melocanna baccifera) possessed the highest number of stems (84.72) followed by Jali Bet (Calamus guruba) (62.5), Kanak (Schima wallichii) (38.89) and Achargula (Grewia microcos) (29.17) per hectare in the studied VCF of Korangpara and Kaprupara in Bandarban (Appendix 1). The number of stems/hectare for tree species were found 297 for Korangpara and 411 for Kaprupara whereas basal area $\left(\mathrm{m}^{2} / \mathrm{ha}\right) 35.19$ and 70.10 . The number of tree species was found $27 \& 31$ at Korang and Kaprupara VCF respectively (Tab. 1).

Tab. 1 Stocking of trees and regenerated species in the study area (Source: Field Surveyed, 2016).

\begin{tabular}{lccccc}
\hline VCF Name & $\begin{array}{c}\text { Stem per ha } \\
(\text { No. })\end{array}$ & $\begin{array}{c}\text { Basal area } \\
\left(\mathrm{m}^{2} / \mathrm{ha}\right)\end{array}$ & $\begin{array}{c}\text { Tree spp. } \\
(\text { No. })\end{array}$ & $\begin{array}{c}\text { Regeneration specimen } \\
(\text { No. })\end{array}$ & $\begin{array}{c}\text { Regeneration } \\
\text { (No./ha) }\end{array}$ \\
\hline Korangpara & 297 & 35.19 & 27 & 30 & 22222.22 \\
\hline Kaprupara & 411 & 70.10 & 31 & 35 & 23680.56 \\
\hline
\end{tabular}

Tab. 2 Distribution of major tree species in the study areas (Source: Field Surveyed, 2016).

\begin{tabular}{|c|c|c|c|c|c|c|c|c|c|c|}
\hline \multirow{2}{*}{ Slope } & \multirow{2}{*}{$\begin{array}{l}\text { No. } \\
\text { Species }\end{array}$} & \multirow{2}{*}{$\begin{array}{l}\text { Total } \\
\text { of all } \\
\text { species }\end{array}$} & \multicolumn{7}{|c|}{ Major species by Number and Percentage } & \multirow{2}{*}{$\begin{array}{l}\text { Total of the } \\
\text { major Species }\end{array}$} \\
\hline & & & $\begin{array}{l}\text { Ulot } \\
\text { kombal }\end{array}$ & Bet & Bamboo & Chapalish & Kanak & Etchri & Achargula & \\
\hline Steep & 22 & 80 & $\begin{array}{l}8 \\
(3.14)\end{array}$ & $\begin{array}{l}20 \\
(7.84)\end{array}$ & $\begin{array}{l}7 \\
(2.75)\end{array}$ & $\begin{array}{l}3 \\
(1.18)\end{array}$ & $\begin{array}{l}9 \\
(3.53)\end{array}$ & $\begin{array}{l}3 \\
(1.18)\end{array}$ & $\begin{array}{l}4 \\
(1.57)\end{array}$ & $\begin{array}{l}54 \\
(21.19)\end{array}$ \\
\hline Moderate & 19 & 100 & $\begin{array}{l}0 \\
(0.00)\end{array}$ & $\begin{array}{l}25 \\
(9.80)\end{array}$ & $\begin{array}{l}20 \\
(7.84)\end{array}$ & $\begin{array}{l}2 \\
(0.78)\end{array}$ & $\begin{array}{l}17 \\
(6.67)\end{array}$ & $\begin{array}{l}3 \\
(1.18)\end{array}$ & $\begin{array}{l}12 \\
(4.71)\end{array}$ & $\begin{array}{l}79 \\
(30.98)\end{array}$ \\
\hline Gentle & 23 & 75 & $\begin{array}{l}0 \\
(0.00)\end{array}$ & $\begin{array}{l}0 \\
(0.00)\end{array}$ & $\begin{array}{l}34 \\
(13.33)\end{array}$ & $\begin{array}{l}0 \\
(0.00)\end{array}$ & $\begin{array}{l}2 \\
(0.78)\end{array}$ & $\begin{array}{l}3 \\
(1.18)\end{array}$ & $\begin{array}{l}5 \\
(1.96)\end{array}$ & $\begin{array}{l}44 \\
(17.25)\end{array}$ \\
\hline
\end{tabular}


In the studied VCF, it was found that Bamboo, Jali Bet, Kanak, Achargula, Ulotkombal (Achryranthes aspera), Etchri (Anogeissus acuminata) and Chapalish (Artocarpus chaplasha) were the major species growing naturally in the hilly VCF. Among the seven species, Bamboo, Jali Bet, Kanak, Achargula were the dominant species in all position of the hills. In gentle slopes of hilly VCF possess 23 species where major species contained $17.25 \%$ including $13.33 \%$ Mulibansh.

According to Tab. 2 Mulibansh grow well in gentle slope of hill because of water availability in this position of hill. In moderate slope of hill, Major species possess almost $31 \%$ in which Jali bet cover near about $10 \%$. In top of the hill where slope was steep, 22 species was found growing well because of availability of sunlight.

Tab.-3 Distribution of Seedlings, Saplings \& Trees per hectare and percentage of major tree species in the study area (Source: Field Surveyed, 2016).

\begin{tabular}{|c|c|c|c|c|c|c|c|c|c|}
\hline \multirow{2}{*}{ Categories } & \multirow{2}{*}{$\begin{array}{l}\text { Total of } \\
\text { all } \\
\text { species }\end{array}$} & \multicolumn{7}{|c|}{ Major tree species by Seedling, Sapling and Tree (Stem) per hectare and percentage } & \multirow{2}{*}{$\begin{array}{l}\text { Total of the } \\
\text { major } \\
\text { species }\end{array}$} \\
\hline & & Achargula & Dumur & Kanak & Etchri & Bamboo & Malakana & Garjon & \\
\hline Seedling/ha & 19687.96 & $\begin{array}{l}2847.22 \\
(14.46)\end{array}$ & $\begin{array}{l}1354.16 \\
(6.88)\end{array}$ & $\begin{array}{l}1145.84 \\
(5.82)\end{array}$ & $\begin{array}{l}1076.39 \\
(5.47)\end{array}$ & $\begin{array}{l}5034.72 \\
(25.57)\end{array}$ & $\begin{array}{l}902.78 \\
(4.59)\end{array}$ & $\begin{array}{l}694.45 \\
(3.53)\end{array}$ & $\begin{array}{l}13055.56 \\
(66.32)\end{array}$ \\
\hline Sapling/ha & 190.34 & $\begin{array}{l}22.23 \\
(11.68)\end{array}$ & $\begin{array}{l}2.78 \\
(1.46)\end{array}$ & $\begin{array}{l}13.89 \\
(7.29)\end{array}$ & $\begin{array}{l}5.56 \\
(2.92)\end{array}$ & $\begin{array}{l}94.44 \\
(49.62)\end{array}$ & $\begin{array}{l}00.00 \\
(00.00)\end{array}$ & $\begin{array}{l}00.00 \\
(00.00)\end{array}$ & $\begin{array}{l}138.9 \\
(72.97)\end{array}$ \\
\hline Stem/ha & 123.63 & $\begin{array}{l}22.22 \\
(19.97)\end{array}$ & $\begin{array}{l}4.17 \\
(3.37)\end{array}$ & $\begin{array}{l}34.73 \\
(28.09)\end{array}$ & $\begin{array}{l}8.33 \\
(6.74)\end{array}$ & $\begin{array}{l}00.00 \\
(00.00)\end{array}$ & $\begin{array}{l}4.17 \\
(3.37)\end{array}$ & $\begin{array}{l}5.56 \\
(4.49)\end{array}$ & $\begin{array}{l}79.18 \\
(66.03)\end{array}$ \\
\hline
\end{tabular}

In Tab. 3 It was found that, Kanak (34.73 stems/ha) and Achargula (22.22 stems/ha) are the dominant species in both mature and sapling stage. In sapling stage, major species contained $73 \%$ of which Mulibansh (dbh more than $5 \mathrm{~cm}$ ) contained $49.62 \%$ (94.44 culms per ha). Seedling per hectare of all species in the studied VCF was near about 20000 where major species as well as dominant species covered 66\% including Mulibanash (5034 culms per ha). It also shows that species from seedling stage to tree stage reduce gradually. Dominant trees show in good survival rate and possess larger percentage.

\subsection{Diameter and Height class of tree species}

From surveyed VCF of Korang and Kapru para in Bandarban district, 149 individuals were found belonging to 39 tree species. The percentage distribution of individual tree species under seven different dbh classes showed that most of the trees (34.89\%) were in 5-15 cm dbh class and the lowest percentage $(2.68 \%)$ was found in dbh range $>55-65 \mathrm{~cm}$. This result showed that sapling stage was much stronger than tree stage. The largest dbh class $(>65 \mathrm{~cm})$ comprised only $6.04 \%$. This finding also showed that the percentage of individual trees decreased with increasing diameter (Fig. 2).

The percentage distribution of tree species under seven different height classes showed (Fig. 3) that one third of the trees (30.87\%) occupied in 6-10 m height class followed by $25.50 \%$ in $11-15 \mathrm{~m}$ height class and $19.46 \%$ in $16-20 \mathrm{~m}$ height class. The lowest percentage (2.01\%) were present in 30-35 $\mathrm{m}$ and $>35 \mathrm{~m}$ height class. The largest height class $(>35 \mathrm{~m}$ ) comprised 3 individuals with 3 species only. The Percentage of distribution of individual species in height classes showed that the number of individuals and species decreased at decreasing rate with the increase of height (Fig. 3). 

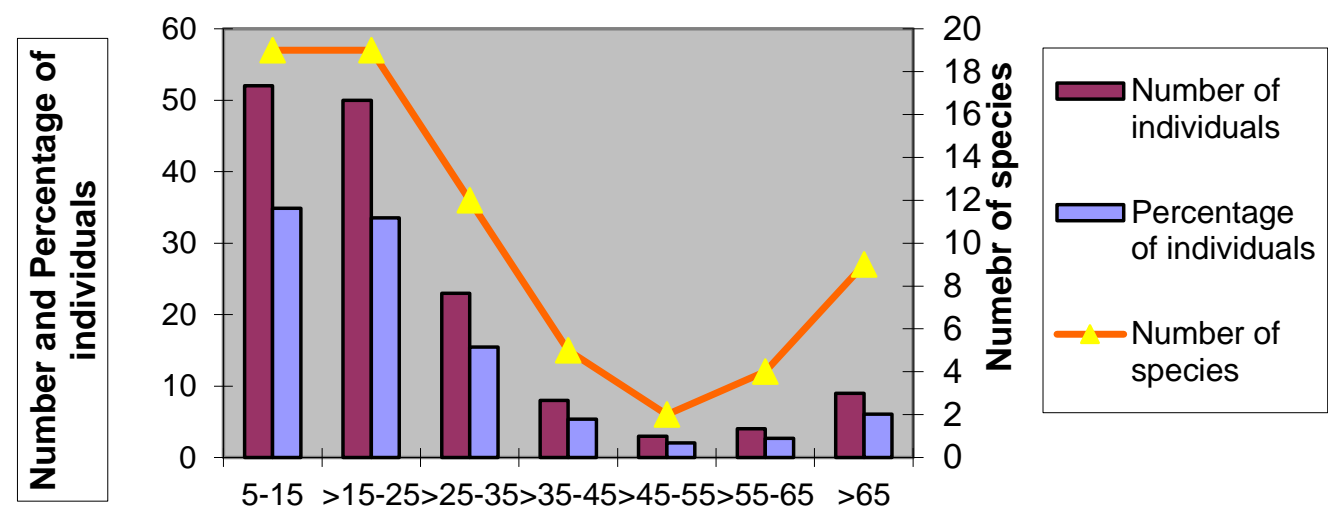

\section{dbh class $(\mathbf{c m})$}

Fig. 2 dbh Class (m) of the tree species in the study area.
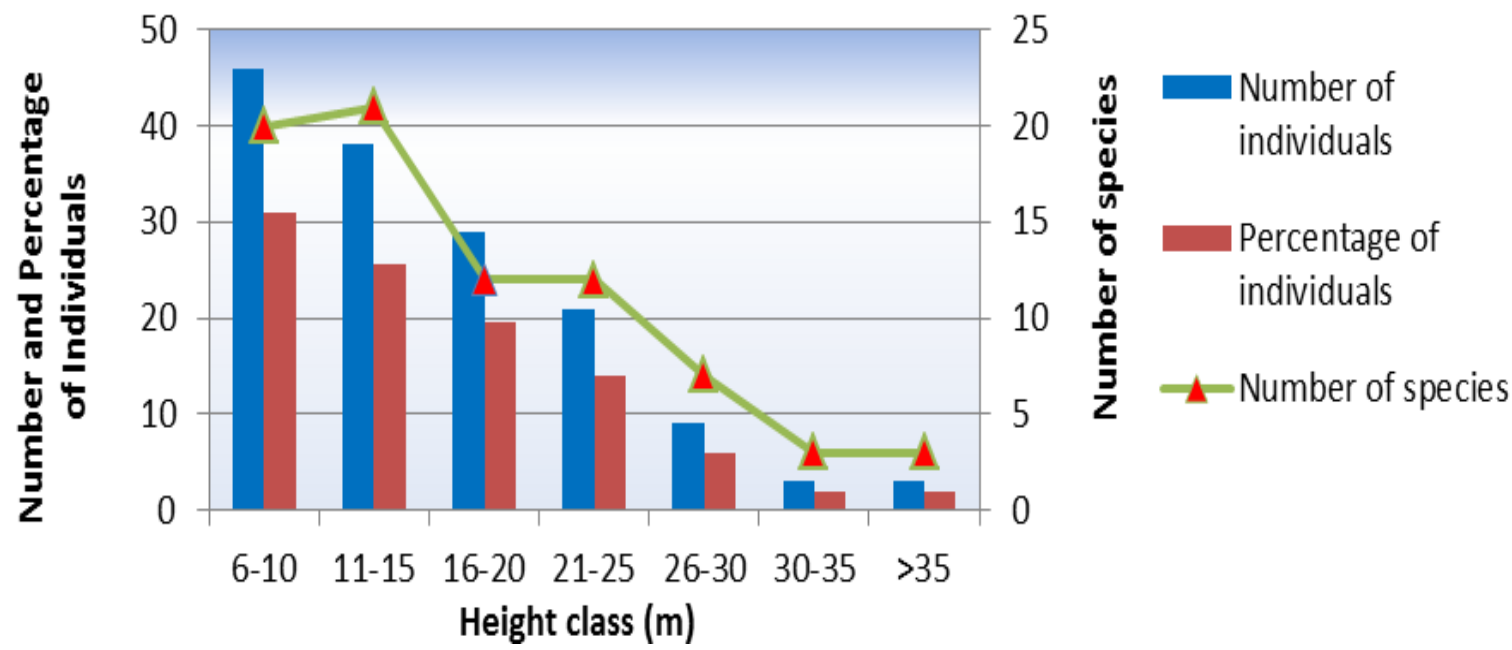

Fig. 3 Height Class (m) of the tree species in the study area.

\subsection{Species Diversity}

The Simpson and Shannon-Weaver diversity index indicates that VCF of Kapru and Kurang Para in Chimbuk hill range was less diversify except middle of the hill or moderate slope of the hill (Tab. 4).

Tab. 4 Tree species diversity in the study areas (Source: Field Surveyed, 2016).

\begin{tabular}{|c|c|c|c|c|c|c|c|c|}
\hline \multirow{2}{*}{ VCF Name } & \multirow{2}{*}{$\begin{array}{l}\text { Hill } \\
\text { position }\end{array}$} & \multirow{2}{*}{ Slope } & \multicolumn{3}{|c|}{ Simpson's diversity index } & \multicolumn{3}{|c|}{ Shannon-Weaver diversity index } \\
\hline & & & Tree & Sapling & Seedling & Tree & Sapling & Seedling \\
\hline \multirow[t]{3}{*}{ Kapru Para } & Top & $\begin{array}{l}\text { Steep } \\
(40 \%-60 \%)\end{array}$ & 0.3165 & 0.2978 & 0.1666 & 1.3654 & 1.0036 & 1.8934 \\
\hline & Middle & $\begin{array}{l}\text { Moderate } \\
(20 \%-40 \%)\end{array}$ & 0.2089 & 0.2870 & 0.1461 & 1.6896 & 1.2715 & 2.0875 \\
\hline & Valley & $\begin{array}{l}\text { Slight } \\
(1 \%-20 \%)\end{array}$ & 0.2037 & 0.3294 & 0.1184 & 1.6377 & 1.1568 & 2.2532 \\
\hline
\end{tabular}




\begin{tabular}{|c|c|c|c|c|c|c|c|c|}
\hline \multirow{2}{*}{ VCF Name } & \multirow{2}{*}{$\begin{array}{l}\text { Hill } \\
\text { position }\end{array}$} & \multirow{2}{*}{ Slope } & \multicolumn{3}{|c|}{ Simpson's diversity index } & \multicolumn{3}{|c|}{ Shannon-Weaver diversity index } \\
\hline & & & Tree & Sapling & Seedling & Tree & Sapling & Seedling \\
\hline \multirow[t]{3}{*}{ Kurangpara } & Top & $\begin{array}{l}\text { Steep } \\
(40 \%-60 \%)\end{array}$ & 0.3968 & 0.3978 & 0.2031 & 1.1684 & 0.9489 & 1.7306 \\
\hline & Middle & $\begin{array}{l}\text { Moderate } \\
(20 \%-40 \%)\end{array}$ & 0.5081 & 0.4954 & 0.2622 & 0.8165 & 0.9307 & 1.4136 \\
\hline & Valley & $\begin{array}{l}\text { Slight } \\
(1 \%-20 \%)\end{array}$ & 0.2333 & 0.4403 & 0.3574 & 1.4607 & 0.8938 & 1.2316 \\
\hline
\end{tabular}

The results of the studied VCF proved that the tree species were equally distributed in top and valley of the hill. Moderate slope of the hill possesses more diversity between two studied VCF. In case of tree and sapling stages tree species show less diversity but seedling stage show higher diversity between the studied VCF.

\subsection{VCF Management Practices}

\section{Religious belief and Purpose in VCF conservation}

We tried to determine the purpose for conservation of VCF in the study area through focus group discussion (FGD). Most of the discussions opined that VCF are conserved for the conservation of water source followed by safety from natural calamities, collection of fruit and other materials to meet emergency needs, medicine, vegetable and spices. Most of the water stream in the study area are comes from the natural hill forest area. This water is used for their daily activities and agro-crop production. Mro religion is based on nature, which plays an important role in the conservation of VCF as well as biodiversity. They do nature worship such as tree, stone, waterfall, cane, etc. As religious belief, nobody can cut the worship trees, cane and trees of surrounding waterfalls. They believe that this worship brings more productivity in agro crop and protect the villagers from diseases, fire and enemy.

\section{VCF Conservation Committee}

There were two committees for conservation of VCF in the studied area. First, customary committee, which was formed since 1976 and 1955 in Kapru and Korang para respectively, and Headmen were the head of the committee. Second, an executive committee was newly formed for the conservation of VCF with nine members. President, Vice president, General Secretary, Treasurer and Executive Member were the different position in the committee. Every family has a representative as member in the new committee. In each committee, there are two female representatives and they were involved in different conservation and awareness activities. The new committee maintains a bank account to deposit monthly savings which will use in alternative income generating activities and reduce forest dependence of the forest dependent people in the studied area. There is no conflict found between the present Executive Committee and the past Customary Committee.

\section{Management rules}

The committee of community collectively sets the rules of VCF management and punishes the person who breaks the rule. In collaboration of both the committees they have developed management rules. Following five rules were found common in the studied VCF: 
(i) Entrance to the VCF and collection of bamboo and its shoots, herbs, shrubs or trees is prohibited. However, resource collection can be done with prior permission from the management committee. For common interest like School, Girza and house construction of poor family, they can collect trees and bamboo from the VCF.

(ii) VCF area cannot be used as grazing site for domestic animals and jhum land.

(iii) Poor, widow, widower or ostrich people can collect bamboo or tree with the permission of VCF management committee.

(iv) Any kind of fire activities, hunting of wild animal is restricted in and around the VCF.

(v) If anybody dies, bamboo or tree can be collected to perform the rituals of the dead body.

\section{Discussion}

Due to increasing populations in the hilly areas of Bangladesh, management system of forest area has changed gradually and the ecological values of forest are decreasing and the financial factors are getting importance day by day. Economic needs of the hilly villagers (mostly ethnic community) are sometimes considered as a potential threat to the forest area such as VCF area. Many VCF already degraded due to collection of fuel wood, house building material and selling of the mother trees as the most of the VCF communities are poor and do not have alternative livelihood sources. Now-a-days, population pressure and changing land use pattern from forest land to agro-farm are considered main threat degradation of VCF. For long term sustainability, capacity and awareness building are the most important factors, both for the VCF communities and policy makers in the region (Baten et al., 2010).

$\mathrm{VCF}$ are also rich in micro-organism in forest floor which are considered as decomposer due to thicker layers of organic debris while most of the non-VCF forest floors exposed to soil erosion and land degradation (Misbahuzzaman, 2009). In Bandarban and as well as in most parts of the CHT landscapes, water sources have become polluted by intensive agricultural practices and sedimentation from erosion, VCF yet remain the only sources of cleanest water in the hills that fulfills domestic water need of the hill dwellers.Mro, an ethnic community lives in Lama, Ruma, Alikadam and Thanchi upazil as near Chimbuk Mountain of Bandarban district. In 1991, the Mro population in Bangladesh was 22,178 and constituted the fourth largest tribe in Chittagong Hill Tracts (Banglapedia, 2014). Like other ethnic community of CHT, they also depend on non-timber forest products for their livelihoods.

The main economic activities in the remote areas are based on traditional survival agriculture system, which is known as shifting cultivation. For centuries, this system has worked effectively without serious deterioration of soil quality and the exhausted jhum plots lay fallow for at least 7-10 years (Chakma, 2002). But due to increasing population, fallow period has reduced and in some case, no fallow can be possible to maintain reducing the production seriously.

Over long period of time, Mro community understood that the importance of VCF for their sustainability in the hilly area. They conserved their VCF by their own customary rules and planted every year by themselves. They plant basically indigenous species along the buffer areas of the hill for conserving core area of natural forest. In our study, we found that core of the natural forest which is managed traditionally in not so old, but managed by fifteen to twenty years ago,but they collect tree for their community purpose not for meeting personal purpose. For this reason, we found less number of the large trees in the natural forest. Nath et al. (1998) described that as the dbh increases, both the number of individual species and stems decreased in Sitapahar forest reserve of Chittagong hill tracts (south) forest division.

A regeneration study was carried out by Hossain et al., (1999) observed that 62 species with average density was 15618 seedlings per ha in the natural forest of CHT (south) forest division. Our study also revealed similar result, as we found that regeneration of VCF was near to 20000 seedlings per hectare with 41 tree species belonging to 28 families. Baten et al., (2010) found 70 woody species 
in the VCF of Bandarban. We also found that Mulibansh (Melocanna baccifera), Jali Bet (Calamus guruba), Kanak (Schima wallichii), Achargula (Grewia microcos), Ulotkombal (Achryranthes aspera), Etchri (Anogeissus acuminata) and Chapalish (Artocarpus chaplasha) are the major species growing naturally in the hilly VCF. In the evergreen forests, the predominant trees are Garjan (Dipterocarpus turbinatus), Kadam (Anthocephalus chinensis), Chapalish (Artocarpus chapalasha),), Boilam (Anisoptera glabra), Civit (Swintonia foribunda), Champa (Michelia excelsa), Kusum (Schleichera oleosa), etc. Bamboos are found in abundance either throughout the area as pure patches or as undergrowth and the commonest bamboo is Muli (Melocanna bambusoides). There has extensive plantation area particularly of teak (Tectona grandis) which implemented by Bangladesh forest department in vacant area, besides the natural forests (Nishat and Biswas, 2010).

Mulibansh and Jali bet is the important non-timber forest product in the studied VCF. The Mro community in study area primarily meets their demand by eating the shoot of this species. For conserving water in the hill these two species play a great role. For this reason, they are trying to change this habit and we found Muli is the dominant species and Jali bet was grown in the buffer areas of forest as these acts as a fencing.

Our study also found that Mro community has some specific purpose in conservation of VCF, such as conservation of water, barrier of natural calamities etc. and also has religious belief which helps them in conservation work. The result also supports the findings of Baten et al., (2010) which carried out in CHT. It is also assumed that a vital element for sustainability of village common forest is recognized acceptance of these areas to protect them, access and tenure regimes (Tiwari, 2003). Beside the forest department, ethnic groups also conserve the forest resources based on mutually agreed rules and regulation which also prevented forest encroachment by outsiders (Thapa \& Rasul, 2006). For administrative convenience, the British Government divided the hill areas into a number of mouzas. Each mouza was placed under a headman and each village within the mouza was placed under a karbari (Rafi and Chowdhury, 2001). In the studied areas, they had two committees for conservation of their forest areas. All member of the community respect the rules set by the committee. Present customary rules, social capital, degree of dependence on forest and good governance are other important factor that encourage in forest resource management (Talwar \& Ghate, 2003).

To reduce the dependency on the natural forest, resource the studied VCF committees have taken different initiatives of income generating activities such as tailoring, handicrafts, grafting and weaving, mixed fruit gardening, poultry, pig \& cattle rearing, cultivation of pumpkin and cucumber, etc. Nishat \& Biswas (2010) and Rasul \& Thapa, (2005) also found that through participation of people in income generating activities and self-reliance reduce the dependency from VCF forest. NGOs have added a new dimension in the forest protection which ensured the community participation and engaged the local government authority (Zaman, et al., 2011).

Now some Protected Areas (PA) is managed by the state forest department through Comanagement approach with a view to ensure sustainability (Chowdhury and Koike, 2010). Mukul et al., 2008 found that effective co-management between PA managers and local forest user groups are necessary to secure the future of PA in Bangladesh. One option, which developed in the community forestry program in Nepal, could be established in forest management is specifying the number of families and size of village to regulating management of a specific forest resources, access to the forests and equitable distribution of benefits among the community members (Wakiyama, 2004; Gautam et al., 2004; DoF, 2011; Adhikari et al., 2007; Acharya, 2002) and this is also found in joint forest management in India (Panigrahi, 2006; Behera \& Engel, 2006; Vemuri, 2008).

The result of this studied VCF are definite that locally managed forest in Lama and Ruma subdistrict of Bandarban district is really rich in tree species as well as in biodiversity (both flora and fauna) but the area is not in larger size. It is clear that VCF are the only remaining forests in some parts of the CHT (Roy, 2000) that are enriched with biodiversity than that of government forests and indigenous 
K. I. Kamrul et al.

resources management technique were sustaining a balance between exploitation and conservation (Baten et al., 2010; Adnan \& Dastidar, 2011). Tree species diversity ensures the existence of herbs, shrubs and local fauna in smaller areas. It has a large scope to protect the extinction of indigenous tree species as well as herbs, shrubs and fauna species. It enlightened other village common forests for conservation of hilly areas for their sustainability as well as ensures shelters for indigenous species.

\section{Conclusion}

Local Mro communities of Chimbuk hill range of Bandarban district set a model for sustainable natural resources management as well as biodiversity conservation in the hilly area. From the present study, it can be concluded that management of VCF is very important for the existence of human society and natural forest conservation in the hilly area and government should take initiatives to make sustainable this management practice.

\section{Acknowledgements}

The authors would like to thank Dr. S M Serajul Haque, Professor, Institute of Forest and Environmental Sciences, University of Chittagong and Bangladesh Forest Research Institute for their valuable advice and support during research work.

\section{References}

Acharya KP (2002) Twenty-four years of community forestry in Nepal. International Forestry Review, 4, 149-156. doi:10.1505/IFOR.4.2.149.17447

Adnan S, Dastidar R (2011) Alienation of the lands of indigenous peoples in the Chittagong Hill Tracts of Bangladesh. Dhaka/Copenhagen: Chittagong Hill Tracts Commission/International Work Group for Indigenous Affairs.

Adhikari B, Williams F, Lovett JC (2007) Local benefits from communityforests in the middle hills of Nepal.Forest Policy \& Economics, 9, 464-478.

doi:10.1016/j.forpol.2005.11.002

Amnesty International (2008) Human rights in the Chittagong Hill Tracts, Onlinedocumentation archive.

Banglapedia (2014) Online edition found on (http://www.banglapedia.org/), last Access on June 20, 2017.

Baten MA, Khan NA, Ahammad R, Misbahuzzaman K (2010) Village common forests in Chittagong hill tracts, Bangladesh: Balance between Conservation and Exploitation. Unnayan Onneshan-The Innovators, Dhanmondi, Dhaka, Bangladesh.

Behera B, Engel S (2006) Institutional analysis of evolution of joint forest management in India: A new institutional economics approach. Forest Policy \& Economics, 8, 350-362.

Chakma HK (2005) Village common forest management by indigenous people. The Daily ProthomAlo, 27th January, 2005.

Chakma S (2002) The Livelihood of Jhumia Farmer: A Case Study in Two Thanas of Khagrachari District, Bangladesh. Institute of Forestry and Environmental Sciences, University of Chittagong, Chittagong, Bangladesh.

Chowdhury MSH, Koike M (2010) An overview on the protected area system for forest conservation in Bangladesh. Journal of Forestry Research (2010) 21(1): 111-118.

DoF (2016) Community forestry. Department of Forests, Government of Nepal.URL (last checked 23 October 2016).

Gupta SD (2008) Effect of human induced activities on soil properties in watershed of Bangladesh, Institute of Forestry and Environmental Sciences, University of Chittagong. In: Ullah, M. 1997. Indigenous technology and knowledge in crop cultivation and tillage watershed area in Chittagong hill tracts. Proceeding on application of indigenous technology knowledge in watershed 
K. I. Kamrul et al.

management in Bangladesh. PMWT/ FARM/ UNDP/ FAO- GCP/ RAS/ 161/ net-ras/ 93/062 Kathmandu, Nepal.

Gautam AP, Shivakoti GP, Webb EL (2004) A review of forest policies, institutions, and changes in the resource condition in Nepal. International Forestry Review, 6, 136-148.

Hossain M, Rokanuzzaman M, Rahman M, Bodiuzzaman M, Miah MA (2013) Causes of Deforestation and Conservation of Madhupur Sal Forest in Tangail Region. Journal of Environmental Science and Natural Resources. 2013;6(2):109-114.

Hossain MK, Azad AK, Alam MK (1999) Assessment of Natural Regeneration Status in A Mixed Tropical Forest at Kaptai Of Chittagong Hill Tracts (South) Forest Division. The Chittagong Univ. J. Sci. 73-79 pp.

Ishaq M (1971) Bangladesh District Gazetteers, Chittagong Hill Tracts. Government Press, Dhaka. 319 pp.

Martinez ND (1966) Defining and measuring functional aspects of biodiversity. In: Gaston, K. J. (eds.) Biodiversity: A biology of number and difference. (Blackwell Science: Oxford). 114-148 pp.

Misbahuzzaman K (2009) Village Common Forests of Chittagong Hill Tracts in Bangladesh: A harbour of forest health and vitality in the degraded landscape. In: Heok Choh, S. (ed.), Extended Abstracts from the Asia and the Pacific Forest Health Workshop- Forest Health in a Changing World, IUFRO World Series Volume 24, International Union of Forest Research Organizations, Vienna, Austria. 30-32 pp.

Misbahuzzaman K, Marma C (2008) Traditional indigenous knowledge based conservation and livelihood strategies for sustainable forest resources management in the uplands of Bangladesh. In: PARROTTA JA, JINLONG L, Heok Choh S (eds.) Sustainable Forest Management and Poverty Alleviation: Roles of Traditional Forest-related Knowledge. IUFRO World Series Volume 21, International Union of Forest Research Organizations, Vienna, Austria. 116-117 pp.

Mukul SA, Uddin MB, Uddin MS, Khan MASA, Marzan B (2008) Protected Areas of Bangladesh: Current Status and Efficacy for Biodiversity Conservation. Proc. Pakistan Acad. Sci. 45(2): 59-68.2008

Nath TK, Hossain MK, Alam MK (1998) Diversity and composition of trees in Sitapahar forest reserve of Chittagong hill tracts (south) forest division, Bangladesh. Annals of Forestry 6 (1): 1-9 pp.

Nishat A, Biswas SR (2010) Community-Based Restoration of Degraded tropical hill Forests: Experiences from Krykhongpara, Chittagong Hill Tracts, Bangladesh. National Institute of Ecology, Jaipur and New Delhi. Bulletin of the National Institute of Ecology 16: 1-11 pp.

Panigrahi R (2006) Democratization of Forest governance: Myths and realities. The Eleventh Biennial Conference of the International Association for the Study of Common Property, Bali, 19-23 June 2006.

Rafi M, Chowdhury R (2001) Counting the Hills: Assessing in Chittagong Hill Tracts. The University Press Limited, Dhaka. 3-32 pp.

Rasul G, Thapa GB (2005) State policies, praxies and land-use in the Chittagong Hill Tracts of Bangladesh. IIED Working Paper. London: International Institute for Environment and Development. URL. http://hdl.handle.net/10535/6189

Roy RCK (2000) Land rights of the indigenous peoples of the Chittagong Hill Tracts, Bangladesh. Copenhagen: International Work Group for Indigenous Affairs (IWGIA).

Shannon CE, Wiener W (1963)The mathematical theory of communication. Univ. Illinois

Simpson, E. H. 1949. Measurement of diversity. Nature, 163-688 pp.

Talwar DM, Ghate R (2003) Community-initiated forest management without land tenure: How feeble, how strong? A study of three villages from central India. The Conference on Politics of the Commons: Articulating Development and Strengthening Local Practices, Chiang Mai, 11-14 July 2003. URL. http://hdl.handle.net/10535/243

Thapa GB, Rasul G (2006) Implications of changing national policies on land use in the Chittagong Hill Tracts of Bangladesh. Journal of Environmental Management, 81, 441453.doi:10.1016/j.jenvman.2005.12.002

Tiwari S (2003) Chittagong Hill Tracts: A preliminary study on gen- der and natural resource management. Ottawa: IDRC. URL. http://hdl.handle.net/10625/30490 
K. I. Kamrul et al.

Vemuri A (2008) Joint Forest Management in India: An unavoidable and conflicting common property regime in natural resource management. Journal of Development and Social Transformation, 5, 8190.

Wakiyama T (2004) Community forestry in Nepal: A comparison of management systems between indigenous forestry and modern com- munity forestry. In: K. Harada, \& M. Nanang (Eds.), Policy Trend Report 2004 (pp. 1-20). Hayama: Institute for Global Environmental Strategies (IGES).

Zaman S, Siddiquee SU, Faruq MAA, Pramanik MR, Katoh M (2011) Reckoning Participatory Forest Management in Bangla- desh: Study from Its Implementation Perspective. Journal of Agricultural Science, 3, 233-239.

\section{Appendix 1}

Tree species observed IVI $<5.00$ in the VCF of Ruma and Lama Upazila at Bandarban district.

\begin{tabular}{llll}
\hline Family & Scientific name & Local name & $\begin{array}{l}\text { Species density } \\
(\text { stems/ha })\end{array}$
\end{tabular}

\begin{tabular}{lllll}
\hline Anacardiaceae & Swintonia floribunda & Sivit & 5.56 & 5.73 \\
Bigononiaceae & Oroxylum indicum & Hona gula & 5.56 & 6.81 \\
Combrataceae & Anogeissus acuminata & Eccri & 12.5 & 11.11 \\
Dilleniaceae & Dillenia indica & Chalta & 5.56 & 6.41 \\
Dipterocarpaceae & Dipterocarpus turbinatus & Garjan & 5.55 & 6.92 \\
& Aniosptera scaphula & Boilam & 2.78 & 76.7 \\
Elaeocarpaceae & Elaeocarpus robusta & Jongli Jalpai & 8.33 & 6.45 \\
Graminae & Melocanna baccifera & Mulibansh* & 84.72 & 29.43 \\
Lythraceae & Lagerstroemia speciosa & Jarul & 8.33 & 5.68 \\
Magnoliaceae & Michelia champaca & Champa & 5.56 & 6.85 \\
Moraceae & Ficus nervosa & Panni dumur & 5.56 & 6.52 \\
Myristacaceae & Myristica longifolia & Amberela & 5.56 & 9.52 \\
Myrtaceae & Syzygium fruticosum & Putijam & 5.56 & 5.97 \\
Palmae & Calamus guruba & Jali bet* & 62.5 & 20.01 \\
Rurseraceae & Garuga pinnata & Shil badi & 4.17 & 10.42 \\
Sapindaceae & Schleichera oleosa & Kusum & 6.95 & 35.7 \\
Sterculiaceae & Achryranthes aspera & Ulotkombol & 11.11 & 5.71 \\
Theaceae & Schima wallichii & Kanak & 38.89 & 27.48 \\
Tiliaceae & Grewia microcos & Achargula & 29.17 & 36.74 \\
Verbenaceae & Gmelina arborea & Gamar & 11.11 & 7.15 \\
\hline *licates NTFP & & &
\end{tabular}

*Indicates NTFP 